\title{
Cytostatic potential of novel agents that inhibit the regulation of intracellular $\mathrm{pH}$
}

\section{P Wong', H-W Kleemann ${ }^{2}$ and IF Tannock ${ }^{* 1,3}$}

'Department of Medical Biophysics, Princess Margaret Hospital/Ontario Cancer Institute, University of Toronto, Toronto, M5G 2M9, Canada; ${ }^{2}$ Aventis Pharma Deutschland GmbH, Industriepark Höchst, 65926 Frankfurt/Main, Germany; ${ }^{3}$ Department of Medical Oncology and Hematology and the Division of Experimental Therapy, Princess Margaret Hospital, University of Toronto, Toronto, M5G 2M9, Canada

Cells within the acidic extracellular environment of solid tumours maintain their intracellular $\mathrm{pH}(\mathrm{pHi})$ through the activity of membrane-based ion exchange mechanisms including the $\mathrm{Na}^{+} / \mathrm{H}^{+}$antiport and the $\mathrm{Na}^{+}$-dependent $\mathrm{Cl}^{-} / \mathrm{HCO}_{3}{ }^{-}$exchanger . Inhibition of these regulatory mechanisms has been proposed as an approach to tumour therapy. Previously available inhibitors of these exchangers were toxic (e.g. 4,4-diisothiocyanstilbene-2,2-disulphonic acid), and/or non-specific (e.g. 5-N-ethyl-Nisopropyl amiloride). Using two human (MCF7, MDA-MB23I) and one murine (EMT6) breast cancer cell lines, we evaluated the influence of two new agents, cariporide (an inhibitor of the $\mathrm{Na}^{+} / \mathrm{H}^{+}$antiport) and S3705 (an inhibitor of the $\mathrm{Na}^{+}$dependent $\mathrm{Cl}^{-} / \mathrm{HCO}_{3}{ }^{-}$exchanger) on the regulation of intracellular $\mathrm{pH}$ (pHi). The cytotoxicity of the two agents was assessed by using clonogenic assays. Our results suggest that cariporide has similar efficacy and potency to 5-N-ethyl-Nisopropyl amiloride for inhibition of $\mathrm{Na}^{+} / \mathrm{H}^{+}$exchange while $\mathrm{S} 3705$ is more potent and efficient than 4,4-diisothiocyanstilbene2,2-disulphonic acid in inhibiting $\mathrm{Na}+$-dependent $\mathrm{Cl}^{-} / \mathrm{HCO}^{-}$exchange. The agents inhibited the growth of tumour cells when they were incubated at low pHe (7.0-6.8), but were non-toxic to cells grown at doses that inhibited the regulation of $\mathrm{pHi}$. Our results indicate that cariporide and S3705 are selective cytostatic agents under in vitro conditions that reflect the slightly acidic microenvironment found in solid tumours.

British Journal of Cancer (2002) 87, 238 -245. doi:10.1038/sj.bjc.6600424 www.bjcancer.com

(C) 2002 Cancer Research UK

Keywords: cariporide; S3705; $\mathrm{Na}^{+} / \mathrm{H}^{+}$antiport; $\mathrm{Na}^{+}$-dependent $\mathrm{Cl}^{-} / \mathrm{HCO}_{3}{ }^{-}$exchanger; intracellular $\mathrm{pH}$

The microenvironment within many solid tumours is known to be acidic (mean extracellular $\mathrm{pH}(\mathrm{pHe}) \cong 6.9-7.0)$ as compared to normal tissues (mean $\mathrm{pHe} \cong 7.4$ ). The acidity in solid tumours is due to the increased production of acidic metabolites such as lactic acid and $\mathrm{CO}_{2}$ and to the limited ability of the tumour vasculature to remove these acidic products of metabolism, which therefore accumulate within the tumour microenvironment. Using a $\mathrm{pH}$-sensitive fluorescent probe and fluorescent microscopy applied to a solid tumour growing in a transparent window, Helmlinger et al (1997) demonstrated a gradual decrease of pHe from 7.4 to 6.7 as the distance from blood vessels increased from $0 \mu \mathrm{M}$ to $200 \mu \mathrm{M}$.

Under acidic conditions, cells regulate their $\mathrm{pHi}$ by buffering protons that enter the cell, and by activating membrane-based ion-exchange mechanisms, of which the most important are the $\mathrm{Na}^{+} / \mathrm{H}^{+}$antiport and the $\mathrm{Na}^{+}$-dependent $\mathrm{HCO}_{3}{ }^{-} / \mathrm{Cl}^{-}$exchanger. While the intracellular buffering capacity serves to minimize the change in pHi during minor influx or efflux of $\mathrm{H}^{+}$or $\mathrm{OH}^{-}$, restoration of homeostasis is achieved by activating the membrane based ion-exchange mechanisms (Murer et al, 1976; Thomas, 1977; Tonnessen et al, 1990).

$\mathrm{Na}^{+} / \mathrm{H}^{+}$antiports are expressed in all mammalian cells. Six isoforms of the $\mathrm{Na}^{+} / \mathrm{H}^{+}$antiports have been identified and named NHE1-6 (Sardet et al, 1989; Orlowski et al, 1992; Tse et al, 1992; Tse et al, 1993; Wang et al, 1993; Klanke et al, 1995; Numata et al, 1998). While NHE1 is found in most cells, NHE2-5 are tissue

*Correspondence: Dr I Tannock; E-mail: ian.tannock@uhn.on.ca

Received I February 2002; revised 26 April 2002; accepted 26 April 2002 specific and NHE6 is expressed in mitochondria (Counillon and Pouyssegur, 2000). The ubiquitous pattern of expression of NHE1 suggests that it is the dominant form that cells use to regulate their cell volume and pHi. When NHE1 is activated by intracellular acidosis, it exports excess $\mathrm{H}^{+}$ions from the cytoplasm to the extracellular environment in exchange for the intake of $\mathrm{Na}^{+}$ions with a 1:1 stoichiometry (Grinstein et al, 1984; Aronson, 1985).

The gene that encodes the $\mathrm{Na}^{+}$-dependent $\mathrm{HCO}_{3}{ }^{-} / \mathrm{Cl}^{-}$exchanger was cloned and named NCBE (Wang et al, 2000). NCBE regulates $\mathrm{pHi}$ by importing $\mathrm{HCO}_{3}{ }^{-}$from the extracellular space into the cell to buffer excess protons, thus inhibiting changes in pHi. The activity of NCBE depends on the presence of extracellular $\mathrm{Na}^{+}$and $\mathrm{HCO}_{3}{ }^{-}$, and on intracellular $\mathrm{Cl}^{-}$ions.

Our laboratory and others have evaluated previously the efficacy of available NHE-1 inhibitors, such as amiloride and its analogue 5 -N-ethyl-N-isopropyl amiloride (EIPA) with the goal of assessing their possible role in the treatment of solid tumours, where they might contribute to cellular toxicity under acidic conditions. These agents are quite effective inhibitors of $\mathrm{Na}^{+} / \mathrm{H}^{+}$exchange but lack specificity (Kleyman and Cragoe, 1988; Newell et al, 1992; Horvat et al, 1993; Murata et al, 1995). Despite their lack of specificity, experimental studies using amiloride and EIPA have suggested that inhibition of NHE-1 might be beneficial to patients with myocardial ischemia (Pierce et al, 1993; Baumgarth et al, 1996). A new inhibitor, cariporide (HOE642) has been developed to inhibit specifically the NHE-1 isoform (Scholz et al, 1995) by competing with $\mathrm{Na}^{+}$for its binding site. Phase II/III clinical trials of cariporide have been completed and suggest that this agent provides patients 
with protection from cardiac ischemia and reperfusion injury (Karmazyn, 2000; Theroux et al, 2000).

Previously, inhibitors of $\mathrm{Na}^{+}$-dependent $\mathrm{Cl}^{-} / \mathrm{HCO}_{3}{ }^{-}$exchange were limited to stilbene derivatives such as 4,4-diisothiocyanstilbene-2, 2-disulphonic acid (DIDS). This agent provides partial non-reversible inhibition of the exchanger and is toxic to cells in vitro at $0.4 \mathrm{~mm}$ and quite toxic in vivo (Yamagata and Tannock, 1996). More recently, investigators from the Aventis Pharmaceutical Company have developed a new inhibitor of the $\mathrm{Na}^{+}$-dependent $\mathrm{Cl}^{-} / \mathrm{HCO} 3{ }^{-}$exchanger, known as S3705 (unpublished data).

Under acidic conditions, proliferation of cells is known to be dependent on the $\mathrm{pH}$ regulatory mechanisms to maintain their intracellular $\mathrm{pH}$ within the range of pHi 7.2-7.4 (Rotin et al, 1989). If NHE-1 and NCBE are inhibited, the pHi of cells might be expected to establish equilibrium with the extracellular $\mathrm{pH}$ (pHe), which would inhibit selectively the metabolism and growth of tumour cells that are in an acidic microenvironment (Bock and Frieden, 1976; Busa and Nuccitelli 1984; Musgrove et al, 1987). Therefore, cariporide and S3705 might have cytostatic effects on cells growing under the acidic conditions that are found in solid tumours although this will depend on the ability of these agents to penetrate tissue to reach these acidic cells. Cells in these regions may be relatively resistant to chemotherapy due to poor drug access, and agents that inhibit the proliferation of cells in acidic regions of tumours might have therapeutic value when used in conjunction with chemotherapy.

In the present article, we characterise the activity of cariporide and S3705 as inhibitors of their respective exchangers, the $\mathrm{Na}^{+}$/ $\mathrm{H}^{+}$antiport and the $\mathrm{Na}^{+}$-dependent $\mathrm{Cl}^{-} / \mathrm{HCO}_{3}{ }^{-}$exchanger, in cultured malignant cells. We measure the $\mathrm{pHi}$ and the rate of pHi recovery after intra-cellular acidification. Finally, we assess the ability of these agents to inhibit cell proliferation and to cause cell death, as a function of $\mathrm{pHe}$.

\section{METHODS}

\section{Cells}

Experiments were performed using murine EMT-6 cells derived from a mammary sarcoma, and two human breast cancer cell lines, MCF7 and MDA-MB231 (both purchased from the American Type Culture Collection). Cells were maintained in $\alpha$-Minimum Essential Medium ( $\alpha$-MEM) with $10 \%$ foetal bovine serum (FBS). The cells were checked periodically to ensure absence of Mycoplasma by staining the cells with Hoescht 33258 . New cultures were reestablished from frozen stock every 3 months. In experiments where cells were grown at different $\mathrm{pHe}$, the cells were maintained in $\mathrm{pH}$-adjusted media. $\mathrm{pH}$-adjusted medium was prepared by mixing $\alpha$-MEM with $10 \%$ FBS, 25 mM HEPES, and the appropriate amount of $\mathrm{HCl}$ or $\mathrm{NaOH}$. The medium was allowed to equilibrate in $95 \%$ air and $5 \% \mathrm{CO} 2$ and its $\mathrm{pH}$ was repetitively re-adjusted during a one week period.

\section{Reagents}

Cariporide, S3705 and rat-chow containing 0.6\% cariporide were supplied by Aventis (Frankfurt, Germany). 5-N-ethyl-N-isopropyl amiloride (EIPA) was obtained from Aldrich (Milwaukee, WI, USA). DIDS, Nigericin and melphalan were purchased from Sigma (Oakville, ON, Canada). 2'7'-bis-(2-caboxyethyl)-5-(and-6)carboxyfluorescein (BCECF) acetoxymethyl ester was purchased from Molecular Probes (Eugene, OR, USA).

\section{Solutions}

Cariporide and S3705 were dissolved in phosphate buffered saline. EIPA was dissolved in 10\% DMSO and DIDS was dissolved in distilled water.
Unless otherwise indicated, all solutions were $\mathrm{HCO}_{3}{ }^{-}$free. Solution A contained $140 \mathrm{mM} \mathrm{NaCl}, 5 \mathrm{mM} \mathrm{KCl}, 5 \mathrm{~mm}$ glucose, $1 \mathrm{~mm}$ $\mathrm{CaCl}_{2}, 1 \mathrm{mM} \mathrm{MgCl}_{2}$, buffered to $\mathrm{pH} 7.4$ with $20 \mathrm{mM} \mathrm{MES/Tris.}$ $\mathrm{NaHCO}_{3}$ solution contained $25 \mathrm{mM} \mathrm{NaHCO}, 115 \mathrm{mM} \mathrm{NaCl}$, and other components identical to those in the Solution A; it was prepared and stored without $\mathrm{NaHCO}_{3}$, which was added immediately before use. N-Methyl-D-glucamine (NMG) solution was prepared as an iso-osmotic replacement of $\mathrm{NaCl}$; the other components were identical to those described above for Solution A. $\mathrm{NH}_{4} \mathrm{Cl}$ solution contained $15 \mathrm{mM} \mathrm{NH}_{4} \mathrm{Cl}$ and other components identical to the NMG solution. $\mathrm{KCl}$ solution contained $20 \mathrm{mM}$ $\mathrm{NaCl}$ and $140 \mathrm{mM} \mathrm{K}^{+}$ions.

\section{Evaluation of $\mathrm{pHi}$ and its regulation in cells grown in monolayer}

Cells grown as a monolayer on a glass coverslip were exposed to $2 \mu \mathrm{g} \mathrm{ml}^{-1}$ of the acetoxymethyl ester BCECF in serum free $\alpha$ MEM at $37^{\circ} \mathrm{C}$ for $30 \mathrm{~min}$. The coverslip was rinsed with PBS and placed into a cuvette using a specially designed holder aligned at an angle of $30^{\circ}$ to the excitation beam of a SLM Aminco Bowman Series 2 fluorescence spectrometer. The holder also served as a cap for the cuvette, minimizing the loss of $\mathrm{CO}_{2}$. The cells were exposed to excitation beams at $495 \mathrm{~nm}$ and $440 \mathrm{nM}$. The ratio of the fluorescence emitted at $525 \mathrm{nM}$ when excited by the $495 \mathrm{nM}$ beam ( $\mathrm{pH}$ dependent emission) to that emitted at $525 \mathrm{nM}$ when excited by the $440 \mathrm{~nm}$ beam ( $\mathrm{pH}$ independent emission) was used to calculate pHi. A calibration curve of the fluorescence ratio against $\mathrm{pHi}$ was made by placing a coverslip into cuvettes containing nigericin and $\mathrm{KCl}$ solution of various $\mathrm{pHe}(7.4-6.2)$ (Thomas et al, 1979).

The ammonium prepulse method was used to achieve intracellular acidification. The cells were placed in $15 \mathrm{mM} \mathrm{NH}_{4} \mathrm{Cl}$ for $30 \mathrm{~min}$. Intracellular acidification was produced when the cells were transferred to $\mathrm{NMG}$ solution free of $\mathrm{NaCl}$ and $\mathrm{NH}_{4} \mathrm{Cl}$ (Boron, 1989).

Following acidification, the NMG solution was replaced with Solution A (containing $140 \mathrm{mM} \mathrm{NaCl}$ ), and the consequent rate of increase in pHi was used to measure the activity of the $\mathrm{Na}^{+}$/ $\mathrm{H}^{+}$exchanger. The efficacy of cariporide and EIPA in inhibiting this exchanger was evaluated by quantitating $\mathrm{Na}^{+} / \mathrm{H}^{+}$exchange in the presence of different concentrations of inhibitors. Similarly, the activity of the $\mathrm{Na}^{+}$-dependent $\mathrm{Cl}^{-} / \mathrm{HCO}_{3}{ }^{-}$exchanger was assessed by replacing the NMG solution with $\mathrm{NaHCO}_{3}$ solution containing $10 \mu \mathrm{M}$ of EIPA (to inhibit the $\mathrm{Na}^{+} / \mathrm{H}^{+}$antiport). S3705 and/or DIDS were added at different concentrations to compare their inhibitory effects on the exchanger. The combined activity of the $\mathrm{pH}$ regulatory mechanisms was measured by replacing the NMG solution with $\mathrm{NaHCO}_{3}$ solution. Measurements of change in $\mathrm{pHi}$ under various conditions were converted to estimates of $\mathrm{H}^{+}$efflux by using the calculations presented previously (Boron, 1989).

To evaluate possible changes in expression of the exchangers induced by exposure to their inhibitors, cells were grown in the presence or absence of $80 \mu \mathrm{M}$ cariporide and $40 \mu \mathrm{M}$ S3705 at different $\mathrm{pHe}$ for up to 7 days then seeded on coverslips and allowed to attach overnight before use. The pHi of the cells, and activity of the exchangers was then evaluated as described above.

\section{Assays of in vitro toxicity}

The toxicity of cariporide and/or S3705 to cells grown under conditions of different $\mathrm{pHe}$ was evaluated by a clonogenic assay. Cells in monolayer were exposed to cariporide $(80 \mu \mathrm{M})$ and/or S3705 $(40 \mu \mathrm{M})$ in $\alpha$-MEM $+10 \%$ FBS $+25 \mathrm{mM}$ HEPES buffered to various $\mathrm{pHe}(7.4-5.9)$. Control cells were exposed to the solvents used for cariporide and S3705. Following a $24 \mathrm{~h}$ incubation period at $37^{\circ} \mathrm{C}$ in $95 \%$ air and $5 \% \mathrm{CO}_{2}$, the cells were 
trypsinized, washed and plated in tissue culture dishes. The plates were incubated for 10-14 days and the colonies were stained with methylene blue. Colonies containing at least 50 cells were counted and the surviving fraction was calculated as the ratio of the plating efficiencies of treated and control plates exposed to the same pHe.

\section{Inhibition of cell proliferation}

Cells were seeded into $25 \mathrm{~cm}^{2}$ flask and left overnight in $\alpha$-MEM. Following the overnight incubation, the medium was replaced with medium adjusted to different $\mathrm{pH}$ with or without $80 \mu \mathrm{M}$ cariporide and $40 \mu \mathrm{M} \mathrm{S} 3705$. The $\mathrm{pH}$-adjusted media was changed every 2 days until the end of the 7-day experiment. At 2-day intervals, one flask was selected at random, the cells were detached with $0.1 \%$ trypsin, and counted. Growth curves were plotted as a function of $\mathrm{pHe}$ in the presence or absence of cariporide and S3705.

\section{RESULTS}

\section{Ability of cariporide and S3705 to inhibit their respective pHi regulatory mechanisms}

We assessed the ability of cariporide to inhibit the activity of the $\mathrm{Na}^{+} / \mathrm{H}^{+}$antiport by measuring $\mathrm{H}^{+}$efflux from cells following intracellular acidification using the ammonium-prepulse method. Our results indicate that cariporide has similar efficacy and potency as EIPA over the range of concentrations that were tested on the MCF7 and EMT6 cell lines (Figure 1). The efficacy of cariporide to inhibit the $\mathrm{Na}^{+} / \mathrm{H}^{+}$antiport of MDA-MB231 cells was tested only at a concentration of $5 \mu \mathrm{M}$. At a concentration of $5 \mu \mathrm{M}$,
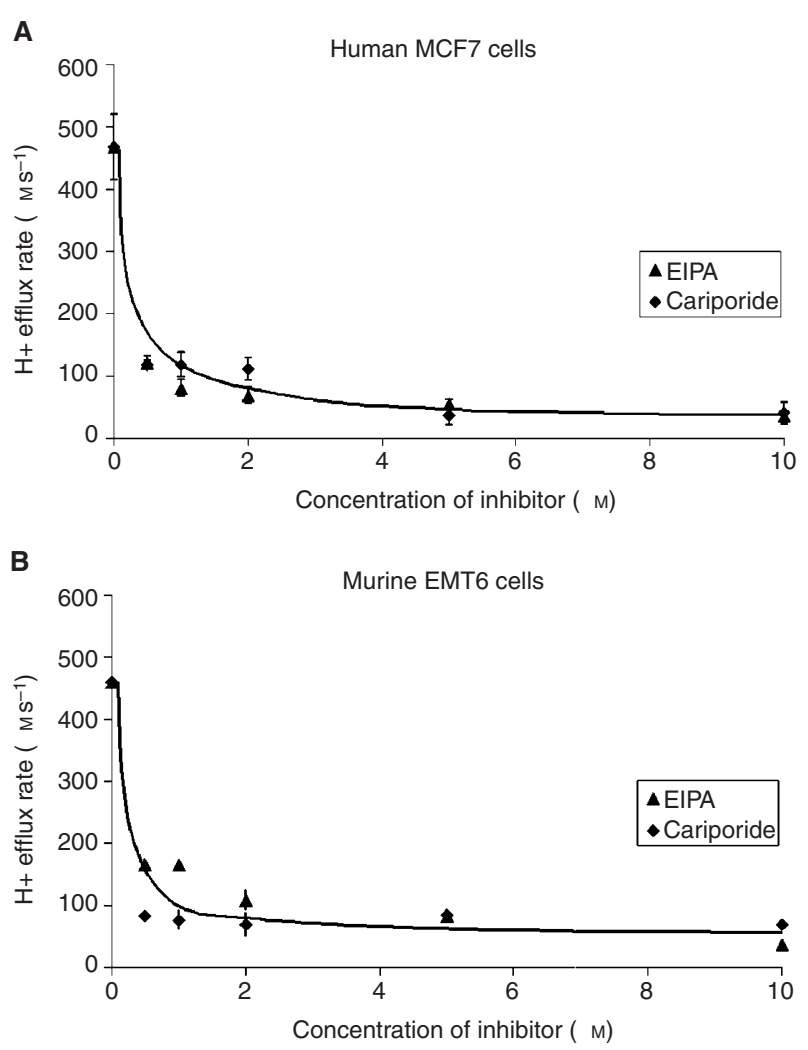

Figure I Comparison of the inhibitory effects of EIPA and cariporide on the activity of the $\mathrm{Na}^{+} / \mathrm{H}^{+}$antiport (measured by the $\mathrm{H}^{+}$efflux rate in $\mu \mathrm{M}$ $\mathrm{s}^{-1}$ ) for (A) MCF7 and (B) EMT6 cells. The results indicated are the mean \pm s.e.m. of at least three experiments. cariporide was able to inhibit up to $90 \%$ of the activity of the $\mathrm{Na}^{+}$/ $\mathrm{H}^{+}$antiport in each cell line. The experiments were repeated in the presence of $10 \%$ FBS, and there was no significant effect of serum on the inhibitory effects of cariporide (data not shown).

Similarly, we compared the efficacy and potency of S3705 and DIDS to inhibit the activity of the $\mathrm{Na}^{+}$-dependent $\mathrm{Cl}^{-} / \mathrm{HCO}_{3}{ }^{-}$ exchanger. In the absence of $10 \%$ FBS, S3705 was more effective and more potent than DIDS (Figure 2). In all three cell lines, up to $80 \%$ of exchanger activity was inhibited by $40 \mu \mathrm{M} \mathrm{S3705} \mathrm{(the}$ efficacy of $\mathrm{S} 3705$ to inhibit the $\mathrm{Na}^{+}$-dependent $\mathrm{Cl}^{-} / \mathrm{HCO}_{3}{ }^{-}$ exchanger in MDA-MB231 cells was evaluated only at $40 \mu \mathrm{M}$ S3705). However, in the presence of $10 \%$ FBS, higher concentrations of S3705 were required to obtain equivalent inhibitory effects although this agent was still more effective and more potent than DIDS (Figure 3).

The contributions of each of the regulatory mechanisms to the recovery of $\mathrm{pHi}$ following acidification, and the maximum inhibitory effects from different agents are summarised in Table 1.

\section{Effects of cariporide and S3705 on the regulation of intracellular $\mathrm{pH}$}

We measured the pHi of MCF7 and MDA-MB231 cells after they were incubated for either $24 \mathrm{~h}$ or 7 days at pHe 7.4 or 6.8 , with or without cariporide and S3705 to evaluate changes in pHi (Figure 4) and proton efflux rate (Figure 5). Our results indicate that both cell lines maintained $\mathrm{pHi}$ at physiological levels $(\mathrm{pHi} \cong 7.3-7.4)$ when they were incubated for $24 \mathrm{~h}$ at $\mathrm{pHe} 7.4$ or 6.8 in the absence of the agents. Incubation in cariporide and S3705 at either pHe caused the pHi of the cells to drop and this decrease in pHi was more marked following incubation at pHe 6.8.
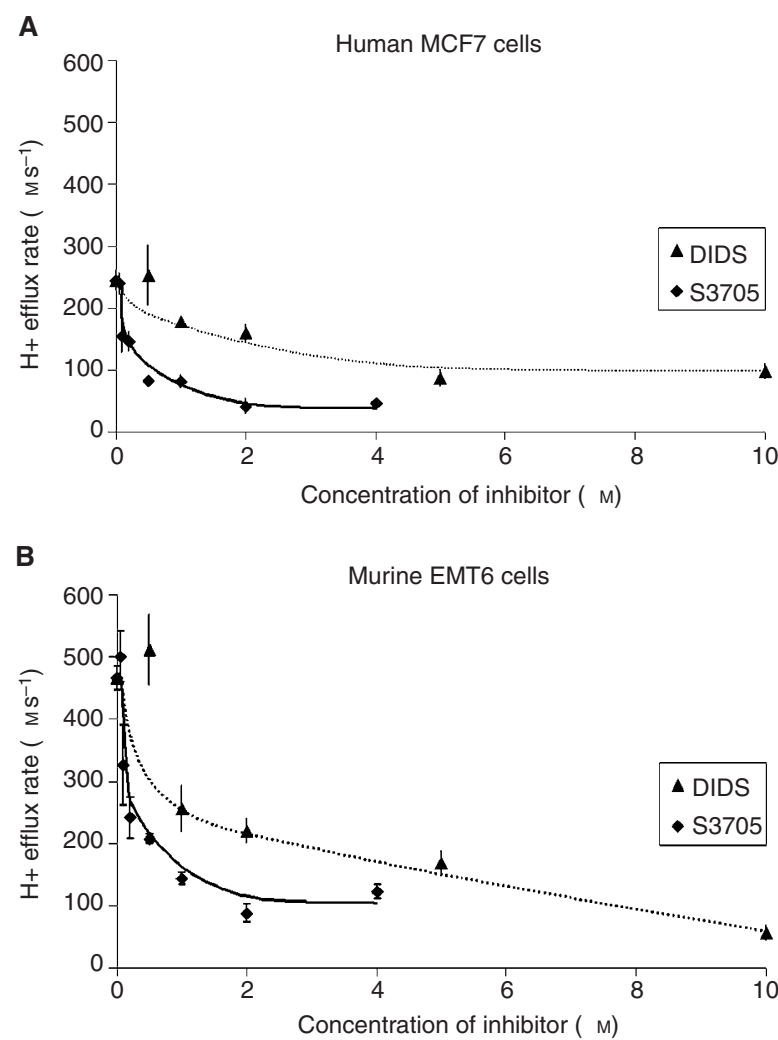

Figure 2 Comparison of the inhibitory effects of DIDS and S3705 on the activity of the $\mathrm{Na}^{+}$dependent $\mathrm{Cl}^{-} / \mathrm{HCO}_{3}{ }^{-}$exchanger (measured by $\mathrm{H}^{+}$ efflux rate in $\mu \mathrm{M} \mathrm{s}^{-1}$ ) for (A) MCF7 and (B) EMT6 cells. Experiments were performed in the absence of serum. The results indicated are the mean \pm s.e.m. of at least three experiments. 
Following 7 days of exposure to cariporide and $\mathrm{S} 3705$ at pHe 7.4 or 6.8, we observed that the proton efflux rates of MCF7 cells increased slightly in comparison with cells incubated at the same levels of $\mathrm{pHe}$ in the absence of the inhibitors (Figure 5). Cells maintained in the absence of the inhibitors at pHe 7.4 and 6.8
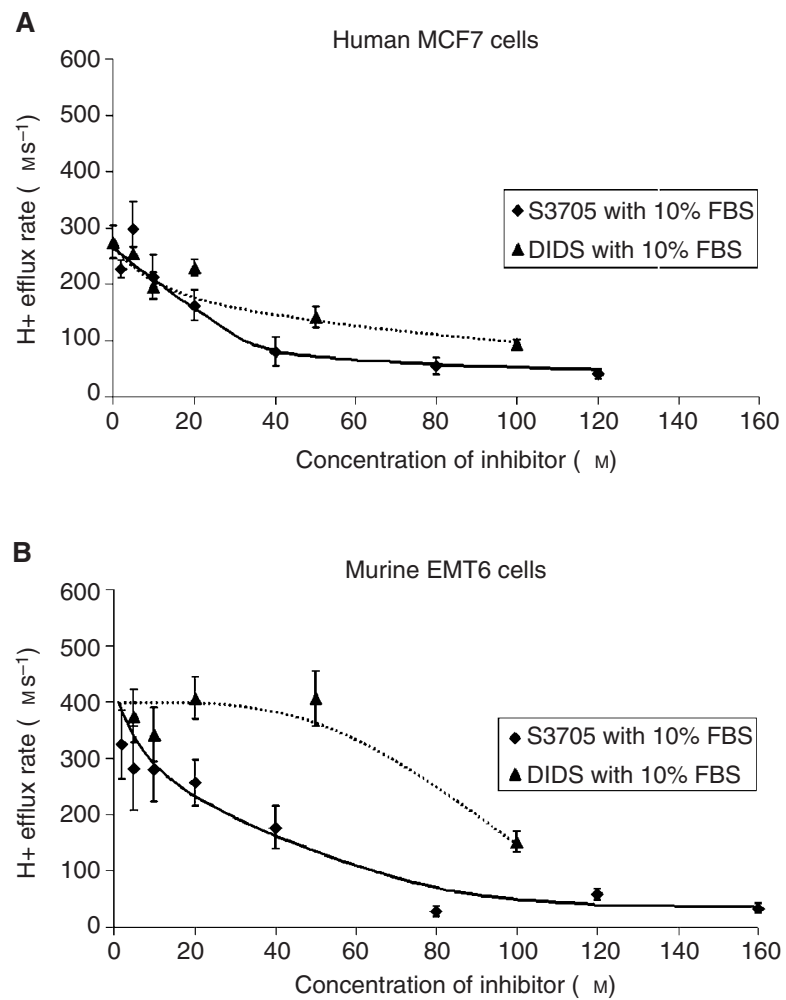

Figure 3 Comparison of the inhibitory effects of DIDS and S3705 in the presence of $10 \%$ foetal bovine serum (FBS) on the activity of the $\mathrm{Na}^{+}$dependent $\mathrm{Cl}^{-} / \mathrm{HCO}_{3}{ }^{-}$exchanger (measured by $\mathrm{H}^{+}$efflux rate in $\mu \mathrm{M} \mathrm{s}^{-1}$ ) for $(\mathbf{A})$ MCF7 and (B) EMT6 cells. The results indicated are the mean \pm s.e.m. of at least three experiments. maintained the same proton efflux rates. Despite the upregulated proton efflux rates, cariporide and $\mathrm{S} 3705$ maintained their activity to inhibit the exchangers in the cells (Figure 5).

\section{Toxicity of cariporide and S3705 to cultured cells}

The results of clonogenic assays indicate that neither compound was toxic to MCF7 or MDA-MB231 cell lines when cariporide $(80 \mu \mathrm{M})$ and $\mathrm{S} 3705(40 \mu \mathrm{M})$ were added individually or together to cells buffered to $\mathrm{pHe}$ in the range of 7.4-5.9 (data not shown).

\section{Inhibition of tumour cell proliferation by cariporide and S3705}

The ability of S3705 and cariporide to inhibit the proliferation of MDA-MB231 and MCF7 cells was assessed by evaluating the growth rate of cells at different $\mathrm{pHe}$ in the presence or absence

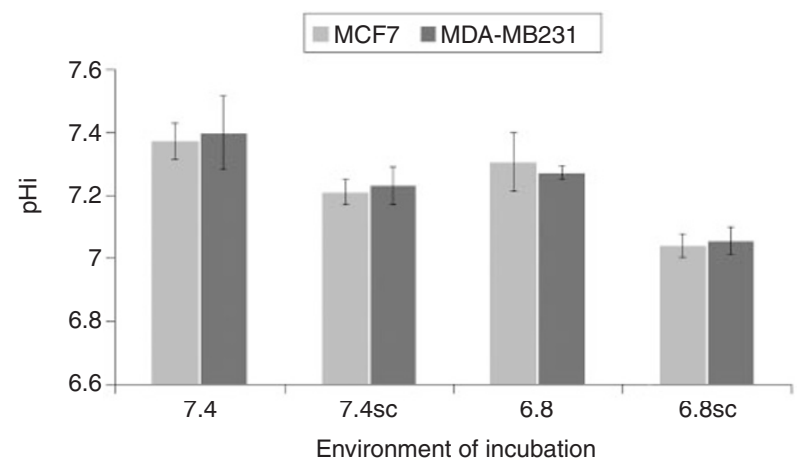

Figure 4 Intracellular $\mathrm{pH}$ (pHi) of MCF7 cells (light histograms) and MDA-MB23I cells (dark histograms) following a $24-h$ incubation period in media adjusted to different pHe (7.4 or 6.8) in the absence or presence of $\mathrm{S} 3705$ and cariporide (SC). The results indicated are the mean \pm s.e.m. of at least three experiments. Student $t$-test indicates that the $\mathrm{pHi}$ of the cells incubated in the presence of the inhibitors is lower than the pHi of cells incubated at the same pHe in their absence (i.e. 7.4 vs $7.4 \mathrm{SC}, 6.8$ vs 6.8SC) ( $P \leqslant 0.02$, both comparisons).

Table I Hydrogen ion efflux rate $\left(\mu \mathrm{M} \mathrm{s}^{-1}\right)$ following intracellular acidification of EMT6, MCF7 and MDA-MB23। cells. Figures in parentheses represent the percentage of residual activity as compared to the total hydrogen ion efflux rate when both exchangers are active. Mean \pm s.e.m. of at least three experiments

\begin{tabular}{|c|c|c|c|c|}
\hline Test solution & Exchanger evaluated & EMT6 & MCF7 & MDA-MB23 I \\
\hline $\mathrm{NaHCO}_{3}$ solution & NHE and NCBE & $\begin{array}{c}868 \pm 99 \\
(100 \%)\end{array}$ & $\begin{array}{l}748 \pm 122 \\
(100 \%)\end{array}$ & $\begin{array}{c}385 \pm 71 \\
(100 \%)\end{array}$ \\
\hline Solution A ( $\mathrm{NaCl})$ & $\begin{array}{l}\text { NHE } \\
\text { NCBE (inactive) }\end{array}$ & $\begin{array}{l}460 \pm 5 \\
(53 \%)\end{array}$ & $\begin{array}{c}468 \pm 52 \\
(63 \%)\end{array}$ & $\begin{array}{c}244 \pm 27 \\
(63 \%)\end{array}$ \\
\hline $\begin{array}{l}\mathrm{NaHCO}_{3} \text { solution }+ \\
10 \mu \mathrm{m} \text { EIPA }\end{array}$ & $\begin{array}{l}\text { NCBE } \\
\text { NHE inhibited }\end{array}$ & $\begin{array}{c}466 \pm 19 \\
(54 \%)\end{array}$ & $\begin{array}{c}245 \pm 15 \\
(33 \%)\end{array}$ & $\begin{array}{c}|3| \pm 35 \\
(34 \%)\end{array}$ \\
\hline $\begin{array}{l}\text { Solution A+ } \\
\qquad 10 \mu \mathrm{M} \text { EIPA }\end{array}$ & $\begin{array}{l}\text { NHE inhibited } \\
\text { NCBE (inactive) }\end{array}$ & $\begin{array}{c}64 \pm 9 \\
(7 \%)\end{array}$ & $\begin{array}{c}37 \pm 3 \\
(5 \%)\end{array}$ & $\begin{array}{c}18 \pm 3 \\
(5 \%)\end{array}$ \\
\hline $\begin{array}{l}\text { Solution } \mathrm{A}+10 \mu \mathrm{M} \\
\text { Cariporide }\end{array}$ & $\begin{array}{l}\text { NHE inhibited } \\
\text { NCBE (inactive) }\end{array}$ & $\begin{array}{c}68 \pm 14 \\
(8 \%)\end{array}$ & $\begin{array}{l}40 \pm 17 \\
(5 \%)\end{array}$ & $\begin{array}{l}43 \pm 0.1 \\
(11 \%)\end{array}$ \\
\hline $\begin{array}{l}\mathrm{NaHCO}_{3} \text { solution+10 } \mu \mathrm{M} \text { EIPA+ } \\
\quad 100 \mu \mathrm{M} \text { DIDS }\end{array}$ & $\begin{array}{l}\text { NHE inhibited } \\
\text { NCBE inhibited }\end{array}$ & $\begin{array}{c}79 \pm 15 \\
(9 \%)\end{array}$ & $\begin{array}{l}98 \pm 11 \\
(13 \%)\end{array}$ & $\begin{array}{l}73 \pm 12 \\
(19 \%)\end{array}$ \\
\hline $\begin{array}{l}\mathrm{NaHCO}_{3} \text { solution+10 } \mu \mathrm{M} \text { EIPA+ } \\
\quad 40 \mu \mathrm{M} \mathrm{S} 3705\end{array}$ & $\begin{array}{l}\text { NHE inhibited } \\
\text { NCBE inhibited }\end{array}$ & $\begin{array}{c}122 \pm 12 \\
(14 \%)\end{array}$ & $\begin{array}{l}47 \pm 6 \\
(6.3 \%)\end{array}$ & $\begin{array}{l}46 \pm 5 \\
(12 \%)\end{array}$ \\
\hline $\begin{array}{l}\mathrm{NaHCO}_{3} \text { solution+10 } \mu \mathrm{M} \\
\quad \text { Cariporide }+40 \mu \mathrm{M} \mathrm{S} 3705\end{array}$ & $\begin{array}{l}\text { NHE inhibited } \\
\text { NCBE inhibited }\end{array}$ & $\begin{array}{c}38 \pm 10 \\
(4 \%)\end{array}$ & $\begin{array}{c}52 \pm 14 \\
(7 \%)\end{array}$ & $\begin{array}{c}20 \pm 8 \\
(5 \%)\end{array}$ \\
\hline
\end{tabular}

For experiments using MDA-MB23I cells, $5 \mu \mathrm{M}$ cariporide was used instead of $\mathrm{I} 0 \mu \mathrm{M} ; \mathrm{NHE}-\mathrm{Na}^{+} / \mathrm{H}^{+}$antiport; $\mathrm{NCBE}-\mathrm{Na}^{+}$-dependent $\mathrm{Cl}^{-} / \mathrm{HCO}_{3}{ }^{-}$exchanger. 


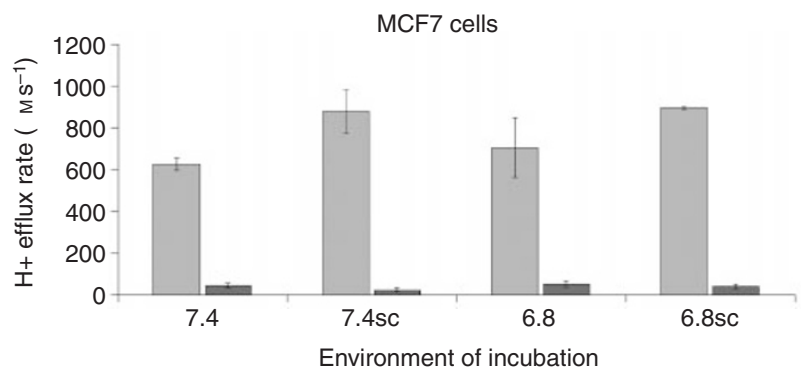

Figure 5 Light histograms: Comparison of the maximum $\mathrm{H}^{+}$efflux rates (measured in $\mu \mathrm{M} \mathrm{s}^{-1}$ ) of MCF7 cells after incubation for 7 days in media adjusted to different pHe (7.4 or 6.8) in the absence or presence of S3705 and cariporide (SC). The agents were not present during evaluation of $\mathrm{H}^{+}$efflux. Dark histograms: Evaluation of $\mathrm{H}^{+}$efflux in the presence of S3705 and cariporide following similar incubation. The results indicated are the mean \pm s.e.m. of at least three experiments. Student $t$-test indicates that there was a significant difference in the $\mathrm{H}+$ efflux rates of cells incubated at pHe 7.4 vs $7.4 \mathrm{SC}(P \leqslant 0.05)$ and a non-significant trend $(P \leqslant 0.10)$ is observed at pHe 6.8.

of the agents (Figure 6). As pHe decreased, both cell lines showed decreased growth rates. The growth rates of the cells at pHe 7.4 and 7.2 in the presence of $5 \mu \mathrm{M} \mathrm{S} 3705$ and $10 \mu \mathrm{M}$ cariporide were not significantly different from the growth rates of the control cells grown in the same pHe. However, MDA-MB231 cells that were incubated with $5 \mu \mathrm{M} \mathrm{S} 3705$ and $10 \mu \mathrm{M}$ cariporide at pHe 7.0 or 6.8 had a slower rate of growth than control cells at the same pHe (data not shown). In contrast, the growth rates of MCF7 cells at pHe 7.0 or 6.8 in the presence of $5 \mu \mathrm{M} \mathrm{S} 3705$ and $10 \mu \mathrm{M}$ cariporide did not differ from untreated MCF7 cells grown at pHe 7.0 or 6.8 . When these experiments were repeated using higher concentrations of S3705 $(40 \mu \mathrm{M})$ and cariporide $(80 \mu \mathrm{M})$, the inhibitory effects of the agents were similar for MDA-MB231 cells (Figure 6A), while MCF7 grown at pHe 7.0 or 6.8 were also inhibited from proliferating as compared to control cells growing in the same pHe (Figure 6B).

\section{DISCUSSION}

Our group and others have tried previously to exploit the acidic microenvironment in solid tumours as a treatment for cancer (Horvat et al, 1993; Newell and Tannock, 1989). Although these prior studies showed that inhibiting the regulation of $\mathrm{pHi}$ and inducing intracellular acidosis could cause tumour cell death, the therapeutic potential of these strategies was limited by toxicity or by lack of specificity of the agents used.

The present study demonstrates the inhibitory effects of cariporide and $\mathrm{S} 3705$ on the $\mathrm{Na}^{+} / \mathrm{H}^{+}$antiport and the $\mathrm{Na}^{+}$-dependent $\mathrm{Cl}^{-} / \mathrm{HCO}_{3}{ }^{-}$exchanger of three malignant cell lines, two of them derived from human breast cancers. Our results suggest that cariporide is as potent and efficient as EIPA while S3705 is more efficient and potent than DIDS. Data from Aventis Pharmaceutical company suggest that a large proportion of S3705 is plasma bound and our results confirm that a higher concentration of S3705 is needed to inhibit $\mathrm{Na}^{+}$-dependent $\mathrm{Cl}^{-} / \mathrm{HCO}_{3}{ }^{-}$exchange in the presence of serum. However, S3705 is more effective and potent than DIDS, either in the presence or absence of serum.

Following mild acidification of the cell lines that were tested, Table 1 shows that regulation of $\mathrm{pHi}$ was due largely to the combined activity of the $\mathrm{Na}^{+} / \mathrm{H}^{+}$antiport and the $\mathrm{Na}^{+}$-dependent $\mathrm{Cl}^{-} / \mathrm{HCO}^{-}$exchanger. Combined application of cariporide and S3705 abolished all but $4-7 \%$ of the rate of $\mathrm{H}^{+}$efflux in these cells. Residual $\mathrm{H}^{+}$efflux might be due to incomplete inhibition of the exchangers, or to the activity of other $\mathrm{pH}$ regulatory mechanisms including other isoforms of $\mathrm{HCO}^{-} / \mathrm{Cl}^{-}$or $\mathrm{Na}^{+} / \mathrm{H}^{+}$ exchangers, $\mathrm{H}^{+}$-ATPases and the transport of $\mathrm{H}^{+}$from the cytoplasm into endosomal vesicles.

It is known that the extracellular $\mathrm{pH}$ in solid tumours is more acidic (mean values of $\mathrm{pHe} \cong 6.9-7.0$ ) than in normal tissues (mean value of $\mathrm{pHe} \cong 7.4$ ), and that the $\mathrm{pHe}$ in tumours decreases with increasing distance from blood vessels (Helmlinger et al, 1997; Wike-Hooley et al, 1984; Vaupel et al, 1989). Although there may be a small increase in the number of apoptotic cells in regions of low $\mathrm{pH}$, cells have a remarkable ability to withstand extracellular acidity when evaluated by clonogenic assay. Both cariporide $(80 \mu \mathrm{M})$ and S3705 $(40 \mu \mathrm{M})$ failed to show toxicity to cells grown in monolayers at doses that inhibited pHi regulation, even at relatively low levels of extracellular $\mathrm{pH}$. This is consistent with previous results for EIPA and DIDS which only become toxic at low pHe if the cells are first acidified by using an ionophore such as nigericin (Newell et al, 1992; Yamagata and Tannock, 1996). Thus cariporide and S3705 are unlikely to be directly toxic to cells in solid tumours, despite the tendency of the microenvironment to be acidic; they might however enhance the activity of agents that cause intracellular acidification (Newell et al, 1992; Yamagata and Tannock, 1996), but this was not evaluated directly.

It has been shown that intracellular acidosis can inhibit cellular metabolism: low pHi may interfere with the folding and function of proteins such as DNA polymerase and phospho-fructokinase (Bock and Frieden, 1976; Busa and Nuccitelli, 1984). Low pHi, in addition to inhibiting the glycolytic pathway can increase consumption of ATP as the cell activates its $\mathrm{H}^{+}$ATPase to export $\mathrm{H}^{+}$to the extracellular environment or into acidic vesicles. Some investigators have reported that intracellular acidosis could also lead to the activation of the apoptotic cascade (Shrode et al, 1997; Park et al, 1999; Matsuyama et al, 2000), while others have shown that low pHi causes cells to accumulate in G1 phase (Musgrove et al, 1987).

To verify the ability of cariporide and S3705 to change the pHi of cells cultured in vitro and thus lead to decreased cellular proliferation, we incubated the cells for $24 \mathrm{~h}$ at pHe 7.4 and 6.8 in the presence or absence of the agents. Following the incubation period, we observed that cells in media adjusted to pHe 7.4 or 6.8 without the agents maintained a higher pHi than the cells that were incubated at the same pHe with the agents present. This may be due to the accumulation of $\mathrm{H}^{+}$ions that cannot be excreted in the presence of cariporide and S3705. We then tested the ability of cariporide and S3705 to maintain their inhibitory effects on the membrane-based exchange mechanisms. MCF7 cells were incubated for 7 days in media adjusted to different $\mathrm{pHe}$ in the presence or absence of the inhibitors. We found that cells grown at $\mathrm{pHe} 7.4$ showed similar $\mathrm{H}^{+}$efflux rates as cells grown at $\mathrm{pHe}$ 6.8. Cells incubated for 7 days with cariporide and S3705 showed up-regulated $\mathrm{H}^{+}$efflux rates at both pHe 7.4 and 6.8. The cells were given ample time $(3-4 \mathrm{~h})$ to restore their $\mathrm{pHi}$ prior to testing their $\mathrm{H}^{+}$efflux rates, thus the increase $\mathrm{H}^{+}$efflux rates are probably not due to increased $\mathrm{H}^{+}$gradients in cells treated with cariporide and S3705. However, when we measured the $\mathrm{H}^{+}$efflux rate in the presence of cariporide and S3705, we found that the agents still provided almost complete inhibition of the exchangers. These results demonstrate the ability of the inhibitors to maintain inhibition of the regulation of $\mathrm{pHi}$, which might lead to the selective inhibition of proliferation of cells growing in acidic conditions.

When we incubated the cells at different pHe $(7.4-6.8)$ in the presence or absence of $10 \mu \mathrm{M}$ cariporide and $5 \mu \mathrm{M} \mathrm{S3705,} \mathrm{concen-}$ trations that would effectively inhibit the exchangers, we found that the inhibitors had minimal effects on the growth rate of cells at physiological pHe (7.4 and 7.2). However, the presence of cariporide and S3705 in media adjusted to pHe 7.0 and 6.8 decreased the rate of growth of the cells. Higher concentrations of these agents were needed to inhibit the growth rate of MCF7 cells. These effects might be useful in inhibiting the tumour proliferation of tumour cells that are situated in slightly acidic regions of tumours. 
A
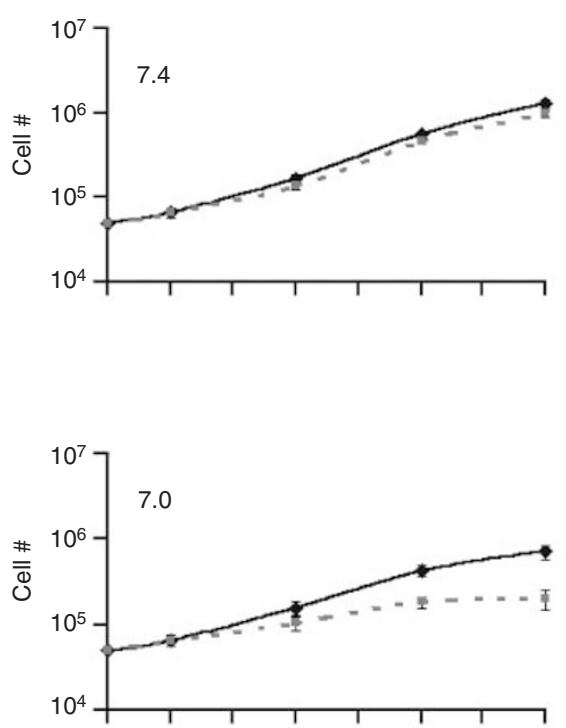

B
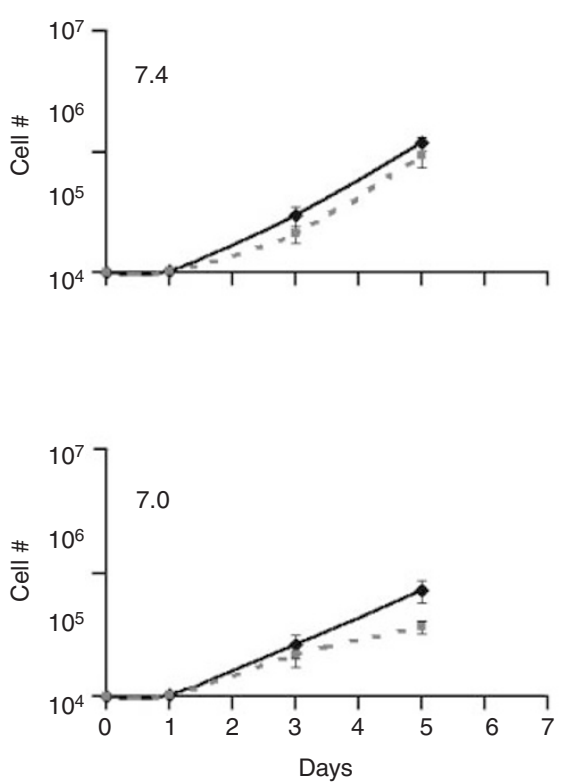

MDA-MB231
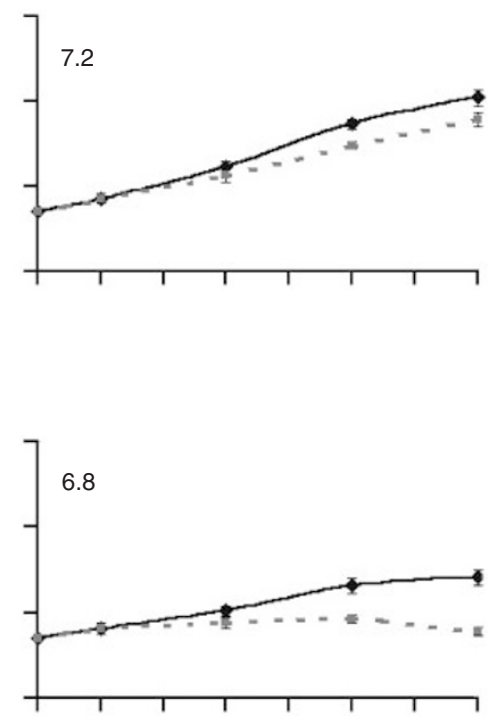

MCF7
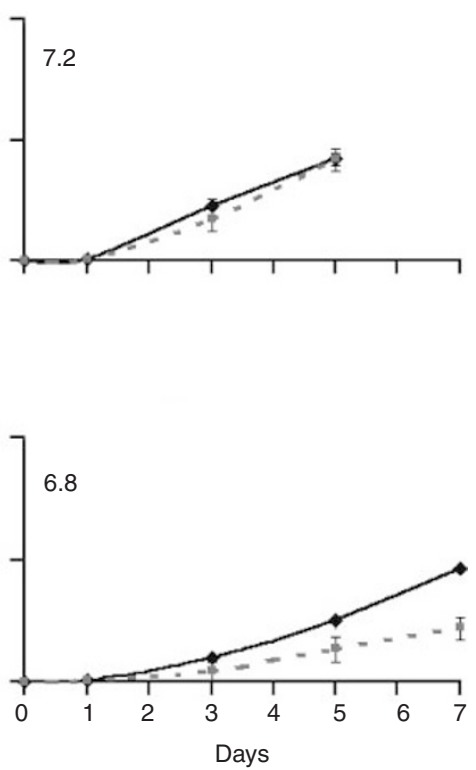

Figure 6 Comparison of the growth rate of (A) MDA-MB23 I and (B) MCF7 cells in media adjusted to different pHe (7.4-6.8) in the absence (solid lines) or presence (dashed lines) of ( $40 \mu \mathrm{M}) \mathrm{S} 3705$ and $(80 \mu \mathrm{M})$ cariporide (SC). Data for MCF7 cells were plotted only from days $0-5$ for pH $7.4-7.0$ because the flasks were too confluent for exponential growth beyond day 5 . The results indicated are the mean \pm s.e.m. of five experiments.

Although cells in such regions may have slower rates of proliferation than more proximal cells, (e.g Hirst et al, 1982), proliferation of cells from such regions is probably responsible for re-growth of many solid tumours following treatment with radiation or with anti-cancer drugs.

Tumour repopulation, or the proliferation between dose fractions of cells that survive the cytotoxic effects of radiotherapy, is recognized as a probable cause of treatment failure (Withers et al, 1988; Maciejewski et al, 1989). There is evidence to suggest that following fractionated irradiation applied to murine and human tumours, the repopulation rate of the tumours accelerates with time (Withers et al, 1988; Begg et al, 1991; Milas et al, 1991; Durand, 1997). This accelerated repopulation may be due to an increased growth fraction (Sham and Durand, 1999), to reduced cell loss or to down-regulation of apoptosis (Thames et al, 1996). Due to accelerated repopulation, higher doses of radiation or accelerated radiotherapy (or radiation given over shorter total time) may be required to achieve tumour control (Withers et al, 1988; Maciejewski et al, 1989).

Unlike radiotherapy, where dose fractions are usually given to the patient once a day, patients undergoing chemotherapy most often receive courses of treatment at less frequent intervals, typically every three weeks. This is necessary to allow recovery (by repopulation) of critical normal tissues such as the bone marrow. Repopulation of tumour cells during the longer intervals between courses of chemotherapy is likely to be an important factor that undermines the efficacy of treatment (Milas et al, 1991; Davis and Tannock, 2000). 
Inhibition of tumour repopulation through the use of selectiveselective cytostatic agents given during radiotherapy or between courses of chemotherapy has substantial potential to increase their therapeutic efficacy. Since repopulation of normal tissues is necessary for their recovery, methods to inhibit repopulation must be tumour specific. Radiation will kill selectively aerobic cells in tumours that are likely to be at higher $\mathrm{pH}$ while anticancer drugs are also likely to exert preferential cell kill against cells that are close to tumour blood vessels because of higher rates of cell proliferation and/or limited tissue penetration of anti-cancer drugs (Tunggal et al, 1999; Tannock et al, 2002). Thus agents such as cariporide and S3705 might decrease the rate of cellular proliferation of cells in acidic environments that survive such treatments.
Experiments to test the potential of S3705 and cariporide to inhibit repopulation in experimental tumours between cycles of chemotherapy are in progress. These agents have been shown to exert in vivo effects to limit myocardial ischaemia; a key question is whether sufficient concentration may be achieved in vivo to inhibit the proliferation of cancer cells under the acidic conditions found in solid tumours.

\section{ACKNOWLEDGEMENTS}

This work was supported by a research grant from the National Cancer Institute of Canada.

\section{REFERENCES}

Aronson PS (1985) Kinetic properties of the plasma membrane $\mathrm{Na}+\mathrm{H}+$ exchanger. Annu Rev Physiol 47: 545-560

Baumgarth M, Beier N, Gericke R (1996) 2-Methyl-5-(methylsulfonyl)benzoyl)guanidine $\mathrm{Na}+/ \mathrm{H}+$ antiporter inhibitors. J Med Chem 40: 2017 - 2034

Begg AC, Hofland I, Kummermehr J (1991) Tumour cell repopulation during fractionated radiotherapy: correlation between flow cytometric and radiobiological data in three murine tumours. Eur J Cancer 27: 537-543

Bock PE, Frieden C (1976) Phosphofructokinase. I. Mechanism of the pHdependent inactivation and reactivation of the rabbit muscle enzyme. J Biol Chem 251: $5630-5636$

Boron WF (1989) Cellular buffering and intracellular pH. In The Regulation of Acid-Base Balance, Seldin DW, Giebisch G (eds) pp 33-56 New York: Raven Press.

Busa WB, Nuccitelli R (1984) Metabolic regulation via intracellular pH. Am J Physiol 246: R409-R438

Counillon L, Pouyssegur J (2000) The expanding family of eucaryotic $\mathrm{Na}(+) /$ $\mathrm{H}(+)$ exchangers. J Biol Chem 275: $1-4$

Davis AJ, Tannock IF (2000) Repopulation of tumour cells between cycles of chemotherapy: a neglected factor. Lancet 1: 86-93

Durand RE (1997) Tumor repopulation during radiotheraphy: quantitation in two xenografted human tumors. Int J Radiat Oncol Biol Phys 39: $803-808$

Grinstein S, Cohen S, Rothstein A (1984) Cytoplasmic pH regulation in thymic lymphocytes by an amiloride-sensitive $\mathrm{Na}+\mathrm{H}+$ antiport. J Gen Physiol 83: $341-369$

Helmlinger G, Yuan F, Dellian M, Jain RK (1997) Interstitial pH and pO2 gradients in solid tumors in vivo: high-resolution measurements reveal a lack of correlation. Nat Med 3: $177-182$

Hirst DG, Denekamp J, Hobson B (1982) Proliferation kinetics of endothelial and tumour cells in three mouse mammary carcinomas. Cell Tissue Kinet 15: $251-261$

Horvat B, Taheri S, Salihagic A (1993) Tumour cell proliferation is abolished by inhibitors of $\mathrm{Na}+/ \mathrm{H}+$ and $\mathrm{HCO} 3-/ \mathrm{Cl}$ - exchange. Eur J Cancer 29: 132 137

Karmazyn M (2000) Pharmacology and clinical assessment of cariporide for the treatment coronary artery diseases. Expert Opin Investig Drugs 9: $1099-1108$

Klanke CA, Su YR, Callen DF, Wang Z, Meneton P, Baird N, Kandasamy RA, Orlowski J, Otterud BE, Leppert M, et al. (1995) Molecular cloning and physical and genetic mapping of a novel human $\mathrm{Na}+\mathrm{H}+$ exchanger (NHE5/SLC9A5) to chromosome 16q22.1. Genomics 25: 615-622

Kleyman TR, Cragoe Jr EJ (1988) Amiloride and its analogs as tools in the study of ion transport. J Membrane Biol 105: 1-21

Maciejewski B, Withers HR, Taylor JM, Hliniak A (1989) Dose fractionation and regeneration in radiotherapy for cancer of the oral cavity and oropharynx: tumor dose-response and repopulation. Int J Radiat Oncol Biol Phys 16: $831-843$

Matsuyama S, Llopis J, Deveraux QL, Tsien RY, Reed JC (2000) Changes in intramitochondrial and cytosolic $\mathrm{pH}$ : early events that modulate caspase activation during apoptosis. Nat Cell Biol 2: 318-325

Milas L, Yamada S, Hunter N, Guttenberger R, Thames HD (1991) Changes in TCD50 as a measure of clonogen doubling time in irradiated and unirradiated tumors. Int J Radiat Oncol Biol Phys 21: 1195-1202

Murata Y, Harada K, Nakajima F, Maruo J, Morita T (1995) Non-selective effects of amiloride and its analogues on ion transport systems and their cytotoxicities in cardiac myocytes. Jpn J Pharmacol 68: 279-285
Murer H, Hopfer U, Kinne R (1976) Sodium/proton antiport in brushborder-membrane vesicles isolated from rat small intestine and kidney. Biochem J 154: $597-604$

Musgrove E, Seaman M, Hedley D (1987) Relationship between cytoplasmic $\mathrm{pH}$ and proliferation during exponential growth and cellular quiescence. Exp Cell Res 172: $65-75$

Newell K, Wood P, Stratford I, Tannock I (1992) Effects of agents which inhibit the regulation of intracellular $\mathrm{pH}$ on murine solid tumours. Br J Cancer 66: $311-317$

Newell KJ, Tannock IF (1989) Reduction of intracellular $\mathrm{pH}$ as a possible mechanism for killing cells in acidic regions of solid tumors: effects of carbonylcyanide-3-chlorophenylhydrazone. Cancer Res 49: 4477-4482

Numata M, Petrecca K, Lake N, Orlowski J (1998) Identification of a mitochondrial $\mathrm{Na}+\mathrm{H}+$ exchanger. J Biol Chem 273: 6951-6959

Orlowski J, Kandasamy RA, Shull GE (1992) Molecular cloning of putative members of the $\mathrm{Na} / \mathrm{H}$ exchanger gene family. cDNA cloning, deduced amino acid sequence, and mRNA tissue expression of the rat $\mathrm{Na} / \mathrm{H}$ exchanger NHE-1 and two structurally related proteins. J Biol Chem 267: $9331-$ 9339

Park HJ, Lyons JC, Ohtsubo T, Song CW (1999) Acidic environment causes apoptosis by increasing caspase activity. Br J Cancer 80: 1892-1897

Pierce GN, Cole WC, Liu K, Massaeli H, Maddaford TG, Chen YJ, McPherson CD, Jain S, Sontag D (1993) Modulation of cardiac performance by amiloride and several selected derivatives of amiloride. J Pharmacol Exp Ther 265: $1280-1291$

Rotin D, Steele-Norwood D, Grinstein S, Tannock I (1989) Requirement of the $\mathrm{Na}+/ \mathrm{H}+$ exchanger for tumor growth. Cancer Res 49: 205-211

Sardet C, Franchi A, Pouyssegur J (1989) Molecular cloning, primary structure, and expression of the human growth factor-activatable $\mathrm{Na}+/ \mathrm{H}+$ antiporter. Cell 56: $271-280$

Scholz W, Albus U, Counillon L, Gogelein H, Lang HJ, Linz W, Weichert A, Scholkens BA (1995) Protective effects of HOE642, a selective sodiumhydrogen exchange subtype 1 inhibitor, on cardiac ischaemia and reperfusion. Cardiovasc Res 29: $260-268$

Sham E, Durand RE (1999) Repopulation characteristics and cell kinetic parameters resulting from multi-fraction irradiation of xenograft tumors in SCID mice. Int J Radiat Oncol Biol Phys 43: 617-622

Shrode LD, Tapper H, Grinstein S (1997) Role of intracellular pH in proliferation, transformation, and apoptosis. J Bioenerg Biomembr 29: 393 - 399

Tannock IF, Lee CM, Tunggal JK, Cowan DS, Egorin MJ (2002) Limited penetration of anticancer drugs through tumor tissue: a potential cause of resistance of solid tumors to chemotherapy. Clin Cancer Res 8: 878-884

Thames HD, Ruifrok AC, Milas L, Hunter N, Mason KA, Terry NH, White RA (1996) Accelerated repopulation during fractionated irradiation of a murine ovarian carcinoma: downregulation of apoptosis as a possible mechanism. Int J Radiat Oncol Biol Phys 35: 951-962

Theroux P, Chaitman BR, Danchin N, Erhardt L, Meinertz T, Schroeder JS, Tognoni G, White HD, Willerson JT, Jessel A (2000) Inhibition of the sodium-hydrogen exchanger with cariporide to prevent myocardial infarction in high-risk ischemic situations : main results of the GUARDIAN trial Circulation 102: $3032-3038$

Thomas JA, Buchsbaum RN, Zimniak A, Racker E (1979) Intracellular pH measurements in Ehrlich ascites tumor cells utilizing spectroscopic probes generated in situ. Biochemistry 18: $2210-2218$

Thomas RC (1977) The role of bicarbonate, chloride and sodium ions in the regulation of intracellular $\mathrm{pH}$ in snail neurones. J Physiol 273: 317-338 
Tonnessen TI, Sandvig K, Olsnes S (1990) Role of $\mathrm{Na}(+)-\mathrm{H}+$ and $\mathrm{Cl}(-)$ $\mathrm{HCO} 3$ - antiports in the regulation of cytosolic $\mathrm{pH}$ near neutrality. Am J Physiol 258:C1117-C1126

Tse CM., Brant SR, Walker MS, Pouyssegur, Donowitz M (1992) Cloning and sequencing of a rabbit cDNA encoding an intestinal and kidney-specific $\mathrm{Na}+\mathrm{H}+$ exchanger isoform (NHE-3). J Biol Chem 267: $9340-9346$

Tse M, Levine S, Yun C, Brant S, Counillon LT, Pouyssegur J, Donowitz M (1993) Structure/function studies of the epithelial isoforms of the mammalian $\mathrm{Na}+/ \mathrm{H}+$ exchanger gene family. J Membr Biol 135: 93- 108

Tunggal JK, Cowan DSM, Shaikh H, Tannock IF (1999) Penetration of anticancer drugs through solid tissue: a factor that limits the effectiveness of chemotherapy for solid tumors. Clin Cancer Res 5: 1583-1586

Vaupel P, Kallinowski F, Okunieff P (1989) Blood flow, oxygen and nutrient supply, and metabolic microenvironment of human tumors: a review. Cancer Res 49: 6449-6465
Wang C-Z, Yano H, Nagshima K, Seino S (2000) Cloning and characterization of a Na+-driven $\mathrm{Cl}-/ \mathrm{HCO} 3$ - exchanger. J Biol Chem 275: $35486-$ 35490

Wang Z, Orlowski J, Shull GE. (1993) Primary structure and functional expression of a novel gastrointestinal isoform of the rat $\mathrm{Na} / \mathrm{H}$ exchanger. J Biol Chem 268: $11925-11928$

Wike-Hooley JL, Haveman J, Reinhold HS (1984) The relevance of tumour $\mathrm{pH}$ to the treatment of malignant disease. Radiother Oncol 2: 343-366

Withers HR, Taylor JM, Maciejewski B (1988) The hazard of accelerated tumor clonogen repopulation during radiotherapy. Acta Oncol 27: $131-$ 146

Yamagata M, Tannock IF (1996) The chronic administration of drugs that inhibit the regulation of intracellular $\mathrm{pH}$ : in vitro and anti-tumour effects. Br J Cancer 73: $1328-1334$ 